\title{
Organization and Management Past to Present:
}

\section{Applicability to Practice in the Modern Enterprise}

Thomas Joseph, Western Governors University, Salt Lake City, USA

\begin{abstract}
This article examined the historical evolution of organization and management theories and their applicability to practice in modern enterprise. Management and organizational theories each add something to the awareness of what managers ought to do. The contemporary approaches of management and organization theory draw upon the historical ideals of classical management and organization theories. Managers must, therefore, value the true concepts of contemporary organizational and management theories that frame the construct and decision-making processes of their particular organizations. Without a doubt, managers who make considerable efforts to transform these theories (classical and contemporary) into reality and practicality could increase productivity more than those who choose to ignore the value of these theories.
\end{abstract}

\section{KEYWORDS}

Adam Smith, Behavioral Management Theory, Chaos Theory, Classical Organizational Theory, Contingency Theory, Frederick Taylor, Henry Fayol, Management Science Theory, Systems Theory

\section{INTRODUCTION}

Drucker (1974) defined management as a practice instead of a science alleging that it is parallel to law, medicine, and engineering. He further emphasized that the basis of management is performance rather than knowledge, the employment of common sense, and leadership. Drucker concluded that as a practice and field of study, management has a long history. Organization has been defined as an economic body that carries out a set of operations more efficiently in a chain-of-command than by market- intervened transactions among firms (Williamson, 1975). According to Jensen and Meckling (1976), organization is a network of contracts between the people in the firm. Ahlstrom (2010) made the assumption that the sole commissions of organizations are to provide jobs for employees; an assumption which has its foundations in the classical works of management (Delios, 2010).

Theories have been described as perspectives from which peoples' world experiences make sense to them (Stoner, Freeman \& Gilbert, 2003). It is more or less a systematic collection of mutually dependent concepts and principles that provide a structure to a substantial knowledge area. Homans (1958) classified theory as a group of pigeonholes or a filing cabinet wherein fact can build up. Theory, essentially, will explain relationships and offer a steady motivation for understanding experiences. 
Theories of management and organization tend to give an explanation for and help understand the fast changing nature of organizational environments. In this study, I examine the historical evolution of theories in management and organization and their applicability to practice in modern enterprise. I examine the Scientific Management theory which comprises of the works of Frederick W. Taylor and Lillian Gilbreth, the Classical Organizational theory encompassing the works of Henri Fayol and Max Weber, Behavioral Management theory, and the Management Science theory. Furthermore, I also discuss contemporary management and organization theories such as Systems theory, Contingency theory, and Chaos theory.

\section{THE EVOLUTION OF MANAGEMENT AND ORGANIZATION THEORY}

The evolution of management and organization emerged around the final decades of the nineteenth century. Hatch and Cunliffe (2006) proposed that the prehistoric period of organization and management theory was formed by two fundamental thoughts namely, sociological and managerial. These two schools of thought focused respectively on the organizational formality and influence within a society as well as the viable predicaments that managers deal with within those environments. According to Perrow (1973), the distinctive interests embodied by sociological and managerial thoughts created tension in organization and management theory relative to both theory and practice. Sociological and managerial ideas represent the basis of scientific management theory.

\section{The Work of Adam Smith}

According to George (1968), the notable economist Adam Smith was one of the first to pronounce a theory that elucidates effective production in work practices that were systematically organized. Smith (1937) compared the relational performances of two dissimilar manufacturing methods and discovered that factory workers who specialized in single/distinct task or limited tasks had greater performance than those who performed multiple tasks for making a specific product (for example, pins). He recognized that higher productivity and efficiency resulted from job specialization. Job specialization denotes or mandates the division of labour among workers in order to improve work efficiency and improve organizational performance. Division of labour outlines the allocation of responsibilities and tasks in an organization (Hatch \& Cunliffe, 2006). Smith concluded that organizational managers should control and organize the organization's work process in order to capitalize on getting the most out of the advantages of division of labour as well as job specialization.

\section{Scientific Management Theory}

The first management theory is widely known as Frederick Taylor's Scientific Management (Drury, 1915). During the late nineteenth century and near the beginning of the twentieth century, Taylor (1911a) posited that national loss in production was as a result of the awkward, unproductive, and ill-directed movements of workers. He constantly tried to replace the concept of management "by rule of thumb" with real time observations resulting in "the one best" practice. Taylor (1911b) also encouraged the systematic training of employees in "the one best practice" instead of allowing these workers individual discretion in their assignments. Additionally, he believed that the workload could possibly be equally distributed among the workers and management with management executing the science and directive and the workers carrying out the labor; hence, each group being responsible for the work that best suits the group.

Frederick Taylor adhered to the idea that the length of time and effort workers spend in producing a finished product or service could be lessened by enhancing specialization and division of labour which could result in a greater efficiency in the production process. Taylor's concepts of scientific management were concerned with an organization's functional type and different techniques needed for motivating employee initiatives and for enhancing work methods (Taylor, 1911a). He submitted five elements for the process of scientific management: science, not a rule-of-thumb, harmony rather 
than discord, cooperation over individualism, maximum production, and the development of each individual to his/her utmost effectiveness and prosperity.

Taylor (1911b) incorporated the elements for the process of scientific management implying that the application of scientific methods to labor could make the most of the advantages of a factory to society resulting in levels of cooperation among management and labor. Hatch and Cunliffe (2006) affirmed that Taylor's system was scientific in nature in that it required managers to utilize research and experiments in order to discover accurate values, standards and processes for lessening production cost while paying higher wages to workers. Science then, would be the tool employed for securing profit maximization. Taylor (1911b) proposed four critical fundamental management principles.

Firstly, there is a requirement to cultivate a science of work that replaces the former rule-ofthumb systems. Taylor (1911b) believed that payment and other forms of rewards must be connected to goal achievements and measurements of work performance and output. He believed that failure to achieve goals would result in a loss of earnings. Second, workers must be scientifically chosen and developed. This entailed providing appropriate training for each worker in order for them to become exceptionally skilled at a specific task. Third, the 'science of work' must be assembled with scientifically selected and trained workers in order to accomplish the best results. Finally, Taylor proposed that work and responsibility should be equally divided among management and workers working together in complete interdependence.

Combined with Taylor's proposals is Gilbreth's motion study (Hatch \& Cunliffe, 2006). The fundamental findings of this concept directed the centrality organizational effectiveness. Gilbreth was particularly concerned about how he could decrease the unnecessary motions that resulted from bricklaying at a construction site. He was able to reduce the motions from 18 to 4. Gilbreth, therefore, recommended that every worker must be engaged in doing his/her personal work, get ready and plan for the next advanced level, and train their successors.

\section{Classical Organizational Theory}

While Taylor focused on the operational level of management as a science, other researchers looked at management from a broader theoretical perspective. The works of Max Weber's (1947) bureaucratic theory and Henri Fayol's (1949) administrative theory represent the most influential concepts relative to classical organizational theory.

Weber (1947) posited that industrialized societies were organized by either a charismatic or traditional form of authority. Traditional authority refers to a hereditary position that is described and preserved by the past. In a charismatic authority, the leadership rights fall on those individuals whose attractive influence for other people justifies their authority. Weber cultivated the concept of bureaucracy, that is, an official system of administration devised for effectively good organizations. Weber's principles of bureaucracy entailed the division of hierarchies in an organization, establishment of strong authority lines, and control. He proposed that organizations utilize comprehensive and exhaustive operating measures for all of the organization's daily tasks. He further believed that organizations that practice the principles of a bureaucratic system will enhance the organization's performance. The bureaucracy, moreover, was predicted as a huge machine for achieving the organizational goals in the most effective possible way.

Henri Fayol (1949) concept of administration focused mainly on the individual obligations of management at a greater granular level; his work was primarily directed at the management layer. He believed that management had five fundamental functions: forecast and plan, organize, command, coordinate, and control. Fayol described forecasting and planning as the manager's way of predicting the future and acting appropriately. Organizing represented the development of the organization's resources (material and human). Command ensured that the organization's processes and actions are operating efficiently. Coordination referred to the configuration and synchronization of the group's efforts. Finally, control implied that the above activities were carried out in conformity to suitable procedures and rules. 
Fayol (1949) developed fourteen administration principles alongside the five primary roles of management. These principles are: specialization and division of labor, authority with responsibility, discipline, unity of command and unity of direction, subordination of personal interest to general interest, staff remuneration, centralization, scalar chain and line of authority, order, equity, tenure stability, initiative, and esprit de corps. Fayol maintained that the application of his proven principles is the preeminent of administering organizational activities. Fayol's five principle roles of management are still vigorously practiced today (Hatch \& Cunliffe, 2006).

\section{Behavioral Management Theory}

Relative to the theoretical concept coined by Taylor, Mary Follet later acknowledged that Taylor's theory of scientific management disregarded or discounted the humane side of the organization (Follet, 1923). Follett indicated that management ignores the significant ways employees are able to contribute to the organization. While Taylor (1911a) depended on the experts of time and motion to analyze the jobs of employees, Follet reasoned that since workers have more knowledge about their jobs, they should be engaged in job analysis and managers should provide them the opportunity to participate in developmental work processes. It was from this basic concept that behavioral management theory emerged.

Behavioral management theory refers to how managers ought to behave in motivating employees to become committed to achieving organizational goals and objectives via increased performance levels. Follet (1923) affirmed to a horizontal view of authority and power. Managers were required to take a closer view of power within the chain of command, soliciting workers' participation. Follett embraced the concept of self-governing organizations pointing out that firms which operate in a democratic environment should hold on to democratic principles. She further implied that power ought to be power instead of power over people.

\section{Management Science Theory}

The work of Chester Barnard (1938) expanded the concepts of management theory proposing that the management of an informal organization was a major function of executive success. He accentuated that the means whereby managers can develop organizations into cooperative social systems was to focus on work integration efforts by communicating goals and paying attention to what motivates workers. Management science theory is, however, a shared-concept of Taylor's (1911a) scientific management concept.

Management science theory utilizes thorough quantitative procedures to make maximum use of an organization's resources. This theory embodies four essential concepts of management: quantitative, operations, total quality management, and management information systems. Quantitative management is the utilization of mathematical techniques that helps managers make decisions relative to new factory location and best investment practices. According to Fabozzi, Focardi, and Jonas (2008), in order for quantitative managers to be at their best, they must possess proprietary informational advantage. In operations management, managers are provided with a set of operational techniques that can be used to analyze various aspects of production systems within the organization for increased efficiency.

Total quality management (TQM) is concerned with the analysis of input, conversion, and output activities. Hur (2009) affirmed that TQM was typically accepted with the anticipation of a change in the manner organizations worked from the start. According to Creech (1995), TQM process engages the whole system, rather than parts of it. It is believed to be a managerial innovation that stresses an organization's complete commitment to customers and a continual improvement to the organization's every process (Westphal, Gulati, \& Shortell, 1997). Management information systems aid managers in constructing information systems that supply information relative to the organization's internal and external events which could further assist in decision-making processes. These concepts of management science provided techniques and tools that managers could utilize for improving decisionmaking qualities while increasing organizational effectiveness and efficiency. 


\section{CONTEMPORARY ORGANIZATION AND MANAGEMENT THEORIES}

The contemporary approaches of management and organization theory draw upon the historical ideals of classical management and organization theories. Under this group of theory are the Systems theory, Contingency theory, and Chaos theory.

\section{Systems Theory}

The systems theory has had a tremendous impact on management disciplines and organizational appreciations. Koontz (1980) defined system as a collection of interconnected or interdependent things incorporated to complete an inclusive goal. It can, however, be characterized by its components interactions and by the interactions that are nonlinear (von Bertalanffy, 1968). A system's nature is changed if one of its parts is removed. It can also be considered as having inputs (such as raw materials and people), processes (such as organizing, and controlling), outputs (such as services), and outcomes (such as example and productivity). Koontz affirmed that systems play a significant role in organizational management that include planning, organizational, and control systems.

Systems theory stresses on the complexity that is present in the component and aspects of a whole and attempt to comprehend the dynamics that exist between those elements. According to von Bertalanffy (1950), systems theory implies that all systems can be replicated under the principle that wholeness will be created by the elements' unification. He further added that the elements are actually the creation of smaller elements which leads to the determination that the processes that create a system are likewise complicated and interactive. Systems theory is characterized and defined within management as a system that is made up of parts which interact with and affect one another.

\section{Contingency Theory}

Contingency theory started around 1950 when experiential and practical studies began to challenge the concepts of classical management belief by finding the one best way to organize. According to Donaldson (1985), the individuals who supported contingency theory believed that the most important aspect was to design and manage an organization that relies on the characteristics of the circumstance in which the organization is located. In essence, the organizational structure or design is contingent on various factors such as its environment, technology, goals, and people. Moreover, the environment's characteristics affect the ability of the organization to attain resources. The fundamental concept of contingency theory is that there is not one best way to lead or design an organization.

Contingency theorists regard conflict as inevitable, but manageable. In Chandler's (1962) study of four large United States companies, he posited that an organization could evolve naturally in order to meet its strategic needs. Chandler's idea implied that in order for an organization to adapt to its environmental changes, it would have to behave in a logical, chronological, and linear manner. Effectiveness and efficiency were functions of management's ability to adapt to environmental changes. Lawrence and Lorsch (1969) also examined how organizations adjusted to suit their environment. In extremely unstable industries, they observed the significance of bestowing upon managers at all levels the right to make decisions over their specific domain. Managers would, however, be liberated to make decisions contingent on the existing situation. In decision-making processes, managers must consider all aspects of their present situation and act on the aspects that are essential to the situation on hand.

\section{Chaos Theory}

Kellert (1993) credited Tom Peters as the advocate of Chaos Theory. Managers have, in the past and present, acted on the concept that organizational events are always controllable. Kellert suggested that chaos theory emerged to acknowledge and recognize that events are hardly ever controlled. Chaos theorists proposed that systems, by nature, surpass complication. As these systems move towards complexity, they tend to become more unpredictable and volatile and must, essentially, apply energy to manage that complexity. As more energy is expended, it creates a need to establish more structure 
to maintain stability. According to Kellert, prolongation of the movement could either propel the unification of one system to another or could lead to system collapse. The survival of the system will depend primarily on the effectiveness of the manager.

Hatch and Cunliffe (2006) identified five characteristics of chaos theory. First, chaos theory ought to be adaptable because of the dynamic nature of complex systems. Second, within a complex system, the response should be local information rather than larger system information. Third, the interaction in a complex or chaos system is nonlinear, implying that there is an existence of numerous components and interactions that can hardly be explained. Fourth, chaos or complex systems undergo changes constantly and evolve time and again in erratic ways because of their nonlinearity. Lastly, in the shape of self-organization, order can materialize from chaos. According to Hatch and Cunliffe, organizations are multifaceted adaptive systems that exist on the border of chaos.

\section{COMPARING SYSTEMS, CONTINGENCY, AND CHAOS THEORIES}

Managing, like other practices, is a skill or know-how. It further entails doing things in connection with the realities of a situation. Fleet and Peterson (1994) proposed that all managers should cultivate three types of skills: conceptual, technical, and human. These skills must be confidently harnessed for the organization's good, employee motivation, and become a crucial part for increasing productivity. Therefore, contemporary organizational managers must realize the critical part they play in their particular organizations in order to attain set goals. They must also realize that there is need for promoting excellence among all organizational workers, especially between managers. Lastly, they must also value the true concepts of contemporary organizational and management theories that frame the construct and decision-making processes of their particular organizations.

Systems theory classifies an organization as a system - a collection of interconnected or interdependent things. These things are, therefore, incorporated to achieve set goals. Similarly, Contingent theory acknowledges the importance of achieving organizational goals by presenting the concept of finding the one best way to organize. For example, organizing, a function of the manager, could result in higher productivity and employee motivation. Adam Smith's (1937) concept of job specialization and division of labor attest to an organization's ability to achieve goals. Additionally, chaos theory adheres to the concept that organizational events are always controllable. Due to the controllable nature of these events, managers can make practical decisions for achieving organizational goals. These decisions could entail dividing work among specialized workers for increasing productivity.

Systems theory also acknowledges that if one part of the system is removed, the nature of the system could change. Chaos theory, likewise, accepts the idea of working together for a common good. As the system becomes more complex, it is imperative to apply more energy that will help alleviate the complexity of the situation. Instead of allowing the complex part to become more complicated, managers must pay more attention to the weak link so that the organization's situation is handled appropriately. Moreover, contingency theory regards conflict as manageable. Within these three concepts of managing an organization, managers can find the tools necessary for maintaining a good organization.

Lastly, systems theory, contingent theory, and chaos theory adhere to the relevance of strong management with organizational change. As markets and industries become more unpredictable and unstable, managers should find ways to deal with events within their environment for improving organizational design, strategy, and structure. Hatch and Cunliffe (2006) admonished managers to analyze situations and trends in their environment. In essence, these three theories have similar ideas relative to organizational and management effectiveness. They also share some differences that make them crucial concepts for organizational efficiency. 


\section{CONTRASTING SYSTEMS, CONTIGENT, AND CHAOS THEORIES}

Systems theory, contingent theory, and chaos theory share three different concepts. Systems theory is characterized as a system made up of parts which interact with and affect one another. Contingency theory, on the other hand, focuses on the idea that organizational structure or design is contingent on various factors such as its environment, technology, goals, and people. The fundamental concept of contingency theory is that there is not one best way to lead or design an organization. Chaos theory accepts that as the systems move towards complexity, they tend to become more unpredictable and volatile. Chaos theorists proposed that systems, by nature, go above complication; systems are complex. According to Kellert (1993), chaos theory emerged to acknowledge and recognize that events are hardly ever controlled. These three theories are different in their approach of organizational management which could cause some form of unbalance in managing a modern enterprise. While a manager sets realistic goals for his/her company, these goals could be interfered by the environmental changes without even realizing that there are hardly ever any changes in events. Additionally, managers could simply believe that there is "one best way" for managing their organization and fail to realize that there are other opportunities or methods that could help develop the organizational structure.

Managers have to deal with the interaction of different parts in the organization, the difficulty of retaining resources due to environmental changes, and manage the constant complexity of the organization. Systems theory appeals to the manager's ability to create a unified functional organization. Contingent theory appeals to the manager's abilities and skills to identify quality resources for performance enhancement. Chaos theory ultimately appeals to the manager's vision and ability to manage in difficult times without deviating from the organization's goals and objectives. The job is unending, yet attainable.

\section{CONCLUSION}

Management, in essence, is the process of designing and preserving an environment for the purpose of efficiently achieving organizational goals. Managers perform the functions of planning, staffing, organizing, leading, and controlling. It is an important activity at all levels in an organization. Drucker (1974) defined management as a practice instead of a science alleging that it is parallel to law, medicine, and engineering. Organization, on the other hand, is a network of contracts between the people in the firm (Jensen \& Meckling, 1976). According to Dean and Bowen (1994), management theory is multidisciplinary. Theory, essentially, will explain relationships and offer a steady motivation for understanding experiences. Management and organizational theories tend to give an explanation for and help understand the fast changeable nature of organizational environments.

There are several management and organizational theories and they each add something to the awareness of what managers ought to do. Adam Smith's concept of job specialization and division of labor elucidates effective production in work practices. Scientific Management theory, developed by Frederick Taylor, proposed that the workload could possibly be equally distributed among the workers and management with management executing the science and directive and the workers carrying out the labor. The works of Max Weber's (1947) bureaucratic theory and Henri Fayol's (1949) administrative theory represent the most influential concepts relative to classical organizational theory. Behavioral management theory refers to how managers ought to behave in motivating employees and encouraging them to perform at higher levels and being committed to achieving the organization's goals and objectives. Follet (1923) attested to a horizontal view of authority and power. Management science theory, a management approach that utilizes thorough quantitative procedures to make maximum use of an organization's resources, entails four essential concepts of management: quantitative, operations, total quality management, and management information systems.

The contemporary approaches of management and organization theory draw upon the historical ideals of classical management and organization theories. Under this group of theory are the Systems 
theory, Contingency theory, and Chaos theory. Systems theory stresses the complexity that is present in the component and aspects of a whole and attempt to comprehend the dynamics that exist between those elements. The fundamental concept of contingency theory is that there is not one best way to lead or design an organization. Contingency theorists regard conflict as inevitable, but manageable. Chaos theorists proposed that systems, by nature, are complex. These three theories share similarity as well as different concepts for effective organizational management in a modern enterprise.

An organization can be realized as an open system that interacts with its environment. A systematic approach to organizational management includes various inputs from the external environment, a process transformation, a system for effective communication, external factors, and ways for reenergizing the system. Without a doubt, managers who make considerable efforts to transform these theories (classical and contemporary) into reality and practicality could increase productivity more than those who choose to ignore the value of these theories. 


\section{REFERENCES}

Barnard, C. (1938). The functions of the executive. Cambridge, MA: Harvard University Press.

Chandler, A. D. Jr. (1962). Strategy and Structure. Cambridge, MA: M.I.T. Press.

Creech, B. (1995). The five pillars of TQM: How to make total quality management work for you. New York: Truman Talley Books/Plume.

Dean, J. W. Jr, \& Bowen, D. E. (1994). Management theory and total quality: Improving research and practice through theory development. Academy of Management Review, 19(3), 392-418. doi:10.5465/ amr.1994.9412271803

Donaldson, L. (1985). In defense of organization theory. Cambridge: Cambridge University Press.

Drucker, P. F. (1954). The practice of management. New York: Harper-Collins.

Drury, H. B. (1915). Scientific management: A History and criticism. New York: Columbia University.

Eastman, W. N. (1994). Assumptions and values in management theory: A historical and pedagogical typology. In Academy of Management Best Papers Proceedings (pp. 169-173). Academic Press.

Fabozzi, F. J., Focardi, S. M., \& Jonas, C. L. (2008). On the challenges of quantitative equity management. Quantitative Finance, 8(7), 649-665. doi:10.1080/14697680802486751

Fayol, H. (1949). General and industrial management. London: Pitman.

Fleet, D. D. V., \& Peterson, T. O. (1994). Contemporary Management (3rd ed.). Houghton Mifflin Company.

George, C. S. Jr. (1968). The history of management thought. Englewood Cliffs, NJ: Prentice-Hall.

Hatch, M. J., \& Cunliffe, A. L. (2006). Organization theory: Modern, symbolic, and postmodern perspectives (2nd ed.). Oxford, NY: University Press.

Homans, G. C. (1958). The Human Group. New York: Harcourt, Brace and World.

Hur, M. H. (2009). The influence of total quality management practices on the transformation of how organizations work. Total Quality Management, 20(8), 847-886. doi:10.1080/14783360903128306

Jensen, M., \& Meckling, W. (1976). Theory of the firm: Managerial behaviour, agency costs and ownership structure. Journal of Financial Economics, 3(4), 305-360. doi:10.1016/0304-405X(76)90026-X

Kellert, S. H. (1993). In the Wake of Chaos: Unpredictable Order in Dynamical Systems. Chicago, IL: University of Chicago Press. doi:10.7208/chicago/9780226429823.001.0001

Lawrence, P. R., \& Lorsch, J. W. (1969). Organization and Environment. Homewood, IL: Richard D. Irwin, Inc.

Perrow, C. (1973). The short and glorious history of organizational theory. Organizational Dynamics, 2-15.

Smith, A. (1937). An inquiry into the nature and causes of the wealth of nations. New York: Modern Library.

Stoner, J. A. F., Freeman, R. E., \& Gilbert, D. R. Jr. (2003). Management (6th ed.). New Delhi: Prentice-Hall.

Taylor, F. W. (1911a). Shop management. New York: Harper \& Brothers.

Taylor, F. W. (1911b). The principles of scientific management. New York: Harper \& Brothers.

Tsoukas, H., \& Knudsen, C. (2003). The Oxford handbook of organization theory: Meta-theoretical perspectives. Oxford, NY: University Press.

von Bertalanffy, L. (1950). An outline of general systems theory. Science, 1(11), 23-29. doi:10.1126/ science.111.2872.23 PMID:15398815

von Bertalanffy, L. (1968). General systems theory: Foundations, developments, applications. New York: Braziller. 
Weber, M. (1947). The theory of social and economic organization (A. H. Henderson and Talcott Parsons Eds.). Glendice, IL: Free Press.

Westphal, J. D., Gulati, R., \& Shortell, S. M. (1997). Customization or conformity? An institutional and network perspective on the content and consequences of TQM adoption. Administrative Science Quarterly, 42(2), 366-394. doi:10.2307/2393924

Williamson, O. E. (1975). Markets and hierarchies: Analysis and antitrust implications. New York: Free Press. 